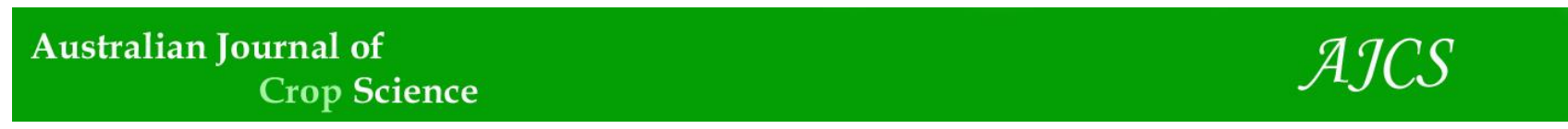

AJCS 11(05):542-547 (2017)

ISSN:1835-2707

doi: 10.21475/ajcs.17.11.05.p331

\title{
Sulphur (S) topdressing and organic compost in production, quality and nutrients accumulation of broccoli seeds at planting time
} Carla Verônica Corrêa*, Aline Mendes de Sousa Gouveia, Natália de Brito Lima Lanna, Bruno Novaes
Menezes Martins, Ana Emília Barbosa Tavares, Veridiana Zocoler Mendonça, Antonio Ismael Inácio
Cardoso, Regina Marta Evangelista

\author{
Department of Horticulture, Botucatu School of Agronomy (FCA), Universidade Estadual Paulista (UNESP), \\ Botucatu, São Paulo state, Brasil
}

*Corresponding author: cvcorrea1509@gmail.com

\begin{abstract}
Most recent studies have focused to the nutrition and fertilizer recommendations of commercial broccoli production. There are a few studies on effect of fertilization on seed production. Although Brazil is a major producer of vegetables, research on seed production of broccoli is scarce. Therefore, it is necessary to develop research lines that increase the information regarding the nutritional requirements for seed production, since in broccoli; there is a 60 days cycle for production, which leads to the understanding of a greater nutritional need of the crop. It is known that sulphur is the second most accumulated nutrient in broccoli seeds. This study aimed to evaluate the effect of doses of sulphur topdressing; and organic compost fertilization on the production and quality of broccoli seeds at planting. The experimental design was a randomized complete block, with ten treatments $(5 \times 2$ factorial design) and four repetitions. Treatments consisted of five doses of $S$ topdressing $\left(0,58,115,173\right.$ and $230 \mathrm{~kg} \mathrm{~S}$.ha $\left.{ }^{-1}\right)$ in the presence or absence of organic compost $\left(100 \mathrm{t} \mathrm{ha}^{-1}\right)$ at planting stage. Seed production (mass and number per plant), mass of thousands of seeds, seed quality (germination, first germination count, germination speed index, seedling length, and seedlings fresh weight); and macronutrients accumulation in the seeds were evaluated. The amount of seeds per plant was 9836 and 8005 seeds per plant in the presence or absence of organic compost, respectively. The seeds fresh mass of 45.7 and $33.1 \mathrm{~g}$ of seeds per plant was produced with and without organic compost, respectively. However, the other characteristics, such as total germination (G), first count (FC), germination index rate (GIR), and seedling fresh mass (SFM) did not reach any significant differences. Regarding to the doses of sulphur, a linear increase was detected to the equation for all macronutrients extracted in the absence of organic compost at planting. However, in the presence of organic compost $\left(100 \mathrm{tha}^{-1}\right)$ at planting, a linear equation was obtained for $\mathrm{P}, \mathrm{Mg}$ and $\mathrm{S}$. For the other macronutrients, a quadratic function occurred, with average values of $2329.2,431.4$ and $326,5 \mathrm{mg} \mathrm{plant}^{-1}$ at the maximum doses estimated in 165.56 , 146.50 and 171.42 for $\mathrm{N}, \mathrm{K}$ and $\mathrm{Ca}$, respectively.
\end{abstract}

Keywords: Brassica oleracea var. italica, germination, macronutrients, mineral nutrition, vigour.

Abbreviations: CEC_cation exchange capacity; LS_length of seedlings; CV_coefficient of variation; G_germination; GIR_germination index rate; $\mathrm{H}+\mathrm{Al}$ _total acidity to pH 7; SFM_seedlings fresh mass; MTS_mass of a thousand seeds; M.O_organic mass; NS_number of seeds per plant; FC_first count; FGC_first germination count; PS_production; SB_sum of bases; V_base saturation.

\section{Introduction}

Brassicas are among the plants within the highest importance in agriculture, as well as for their nutritional values. Among brassicas, there are broccoli, cauliflower, cabbage, kale, radish, turnip and others (Latté et al, 2011). There are still a few studies related to the production and quality of the seeds; although, there is a lot of research on the production and benefits of these vegetables (Traka and Mithen, 2009; Konstantopoulou et al., 2010; Abd El-Hamed and Elwan, 2010; Dinkova-Kostova and Kostov, 2012; Veeranki et al., 2013).

In brassicas, seeds production cycle has greater importance than vegetable production itself. The amount of produced seeds in brassica is reduced under low soil fertility conditions leading to reduction in quality. Magro et al. (2010) reported an increase in the productivity of broccoli seeds, without any difference between seeds germination and vigour under poor soil condition in the presence of organic compost $\left(120 \mathrm{t} \mathrm{ha}^{-1}\right)$.
Therefore, they concluded that organic compost may be an alternative in the production of broccoli seeds, as it slowreleases the nutrients throughout the entire cycle. However, the amount of organic compost may not be feasible from a practical and economic point of view.

Regarding to the nutrient accumulation in the seeds, it has been observed that sulphur is the second most accumulated nutrient in broccoli. However, there are no studies on application of sulphur in the production of broccoli seeds. Corrêa et al., 2016 evaluated treatments of five rates of sulphur in form of ammonium sulphate $(0,31,62,93$ and 124 $\left.\mathrm{kg} \mathrm{ha}^{-1}\right)$ with or without organic compost $\left(100 \mathrm{t} \mathrm{ha}^{-1}\right)$ in broccoli single-head at planting time. They observed that head diameter, head height and fresh mass increased in all treatments by adding organic compost. A quadratic effect was observed for head fresh mass and head height by applying organic compost $\left(100\right.$ tha $\left.^{-1}\right)$, as the maximum values were 
$620.6 \mathrm{~g}$ and $17.2 \mathrm{~cm}$ at the rate of 66.9 and $49.2 \mathrm{~kg} \mathrm{~S} \mathrm{ha}^{-1}$, respectively. The focus of this research is at seed production, in which the information is scarce. The cycle and management for broccoli seed production is completely different from those being conducted for fresh vegetable consumption. There is an at least two months increase in the seed production cycle, compared to vegetable production cycle. Therefore, the efficient nutritional management must be proportional to this increased cycle. In this way, the cover fertilization must be different from the recommended fertilizers for the production of broccoli produced for fresh human consumption.

The brassicas are large extractors of soil nutrients. Among the macronutrients, sulphur (S) is extracted in large quantities (Rathke et al., 2006; Berry et al., 2010). S is an essential nutrient for plant growth, as it forms amino acids, vitamins, cofactors and secondary products, such as glucosinolates (Buchanan et al., 2015). Thus far, a few studies have been conducted to verify the response of brassicas seed production to sulphur under tropical conditions.

Furthermore, as the seed production cycle of broccoli is long (more than 120 days), perhaps the organic compost that is present in soil or added alter, cannot provide the required amount of sulphur at all stages of the cycle for the full development of plants and seeds and may require the topdressing application of nutrients.

Given all the above, the aim of this study is to assess whether there is an effect on the production, quality and extraction of nutrients in broccoli seeds by doses of sulphur topdressing and the presence or absence of organic compost at planting time.

\section{Results and Discussion}

\section{Seed production}

The interaction between $\mathrm{S}$ doses and organic compost did not cause a statistical significant difference for seeds production per plant either for the number of seeds or seeds fresh mass. But, the numbers of seeds and seed fresh mass increased in the presence of organic compost at planting time (Table 1). It is noteworthy that this result was obtained in a soil with high nutrient availability, besides that inorganic fertilizer was applied at planting and later on, by topdressing. Therefore, it proves the importance of organic fertilizer in the production of broccoli seeds.

Magro et al. (2010) reported an increase in the production of broccoli seeds in the presence of organic compost (120 t $\mathrm{ha}^{-1}$ ), highlighting that this fertilization was the only source of nutrients for all plants throughout the entire cycle, as they did not held topdressing fertilization. At the beginning of the reproductive stage, the nutrition requirements is more intense in most species, also critical at seeds formation, because a considerable amount of nutrients are transported to them (Carvalho and Nakagawa, 2012). Thus, any organic compost which acts as natural slow-release fertilizers to plants had probably an effect during seed formation.

The amounts of seeds per plant were 9836 and 8005 in the presence or absence of organic compost, respectively. The seeds fresh mass were 45.7 and $33.1 \mathrm{~g}$ of seeds per plant, with and without organic compost, respectively (Table 1). Thus, these results were much higher than those reported by Magro et al. (2010), who obtained 2758 and $15.9 \mathrm{~g}$ of seeds per plant. However, they conducted experiment with low initial soil fertility. In addition to that they did not use any other topdressing fertilization, such as organic or inorganic fertilizers.
The seed production (number and fresh mass) exhibited a linear increase by enhancing the doses of sulphur (Fig. 1). But, the increase was observed in the treatment that there was no organic topdressing, showing a positive response of broccoli seeds to sulphur. There was no statistical difference by applying organic compost $\left(100 \mathrm{tha}^{-1}\right)$ if compared to the doses of sulphur, i.e. $45.7 \mathrm{~g}$ and 9836.0 for seeds fresh mass per plant and number of seeds, respectively. Probably, all the organic compost had already been released all necessary nutrients, according to Magro et al. (2010). According to Abbey et al. (2002); Eriksen et al. (2004); Biswas and Tewatia (1991), broccoli fertilization has to contain sulphur in its composition, as it is such high sulphur demanding crop. Schonhof et al. (2007) observed an increase in the broccoli head mass when applied sulphur. The interaction between nitrogen and sulphur affects important growth parameters, such as biomass and yield, as $\mathrm{S}$ is an essential constituent of enzymes when associated with nitrogen metabolism, i.e. nitrate reductase and nitrite reductase (Salvagiotti and Miralles, 2008; Carfagna et al., 2011).

Thus, we obtained an increase of 227 in seeds and $0.8 \mathrm{~g}$ of seeds per plant for every $10 \mathrm{~kg} \mathrm{~S}^{-1}$. In the control ( 0 dose $)$, we estimated 5394 seeds and $23.82 \mathrm{~g}$ of seeds per plant; while at the highest $\mathrm{S}$ dose (at $230 \mathrm{~kg} \mathrm{~S} \mathrm{ha}^{-1}$ ) plant produced 10608 seeds and $42.2 \mathrm{~g}$ of seeds per plant, meaning that production increased by $77 \%$.

Despite the importance of sulphur in broccoli, there is no study on application of $\mathrm{S}$ that gives any solid recommendation for using such nutrient and/or technique on its seed production.

Regarding to the mass of a thousand seeds, higher values were obtained in the presence of organic compost at planting, if compared to the absence of the same (Table 1). Also, a linear effect was observed for sulphur doses (Fig. 2). Thus, results varied from $4.34 \mathrm{~g}$ (zero dose) to $4.80 \mathrm{~g}$ (at the highest dose of $230 \mathrm{~kg} \mathrm{~S} \mathrm{ha}^{-1}$ ), when organic topdressing was not held. By applying $100 \mathrm{tha}^{-1}$ of organic compost, there was no effect on the $S$ doses, with an average of $4.60 \mathrm{~g}$. Therefore, applying organic mass has met the plants need at planting, whereas the $\mathrm{S}$ topdressing compost did not show any significant difference in the presence of organic compost.

These values were lower than the one reported by Magro et al. (2010) (i.e. 5.8g) but higher than those reported by George (2009) for cauliflower (2.8g) and cabbage (3.3g). Despite the fact that most Brazilian soils are poor in sulphur and organic mass, a few studies have been conducted in order to verify the response of brassica to doses of sulphur (Corrêa et al., 2013). Most of the sulphur found in the soil is in organic form $(95 \%)$, in addition to be the main source of nutrient to plants. However, there was a positive response to $\mathrm{S}$ topdressing application even at the highest dose of organic compost $\left(100 \mathrm{t} \mathrm{ha}^{-1}\right)$, showing that for the production of broccoli seeds, only the organic mass are not enough to meet the plant's need to achieve the full productive potential. Thus, the application of inorganic sulphur is important to increase the production of seeds. According to Raij et al. (1997), besides the organic compost, there are other sources of sulphur, such as sulphate and gypsum.

\section{Seed quality}

For all characteristics related to seed quality, there was no statistical significant difference in analysis of variance and in regression ( $\mathrm{F}$ was not significant for doses and interaction) with regards to the doses of sulphur. In the presence or absence of organic compost, a few traits were affected (Table 1). The highest seedling length was observed in the treatment 
Table 1. Production (PS) and number of seeds per plant (NS), mass of a thousand seeds (MTS), total germination (G), first count (FC), germination index rate (GIR), seedlings length (SL) and seedlings fresh mass (SFM) in the germination test, in broccoli seeds in the presence or absence of organic compost $\left(100 \mathrm{t} \mathrm{ha}^{-1}\right)$ before planting.FCA/UNESP, São Manuel, 2014.

\begin{tabular}{|c|c|c|c|c|c|c|c|c|}
\hline Compost $\left(\mathrm{t} \mathrm{ha}^{-1}\right)$ & $\begin{array}{l}\text { PS } \\
(\mathrm{g})\end{array}$ & NS & $\begin{array}{c}\text { MTS } \\
(\mathrm{g})\end{array}$ & $\begin{array}{c}\mathrm{G} \\
(\%)\end{array}$ & $\begin{array}{l}\mathrm{FC} \\
(\%)\end{array}$ & GIR & $\begin{array}{c}\mathrm{SL} \\
(\mathrm{cm})\end{array}$ & SFM (g) \\
\hline 0 & $33.1 \mathrm{~b}$ & $8005 \mathrm{~b}$ & $4.2 \mathrm{~b}$ & $98.6 \mathrm{a}$ & $98.6 \mathrm{a}$ & $32.8 \mathrm{a}$ & $3.2 \mathrm{~b}$ & $56.5 \mathrm{a}$ \\
\hline 100 & $45.7 \mathrm{a}$ & $9836 \mathrm{a}$ & $4.7 \mathrm{a}$ & $99.3 \mathrm{a}$ & $99.3 \mathrm{a}$ & $33.9 \mathrm{a}$ & $3.6 \mathrm{a}$ & $59.4 \mathrm{a}$ \\
\hline $\mathrm{CV}(\%)$ & 17.6 & 16.9 & 7.3 & 2.82 & 2.82 & 5.8 & 15.6 & 12.9 \\
\hline
\end{tabular}

Means followed by different letters differ by Tukey test at $5 \%$ probability.
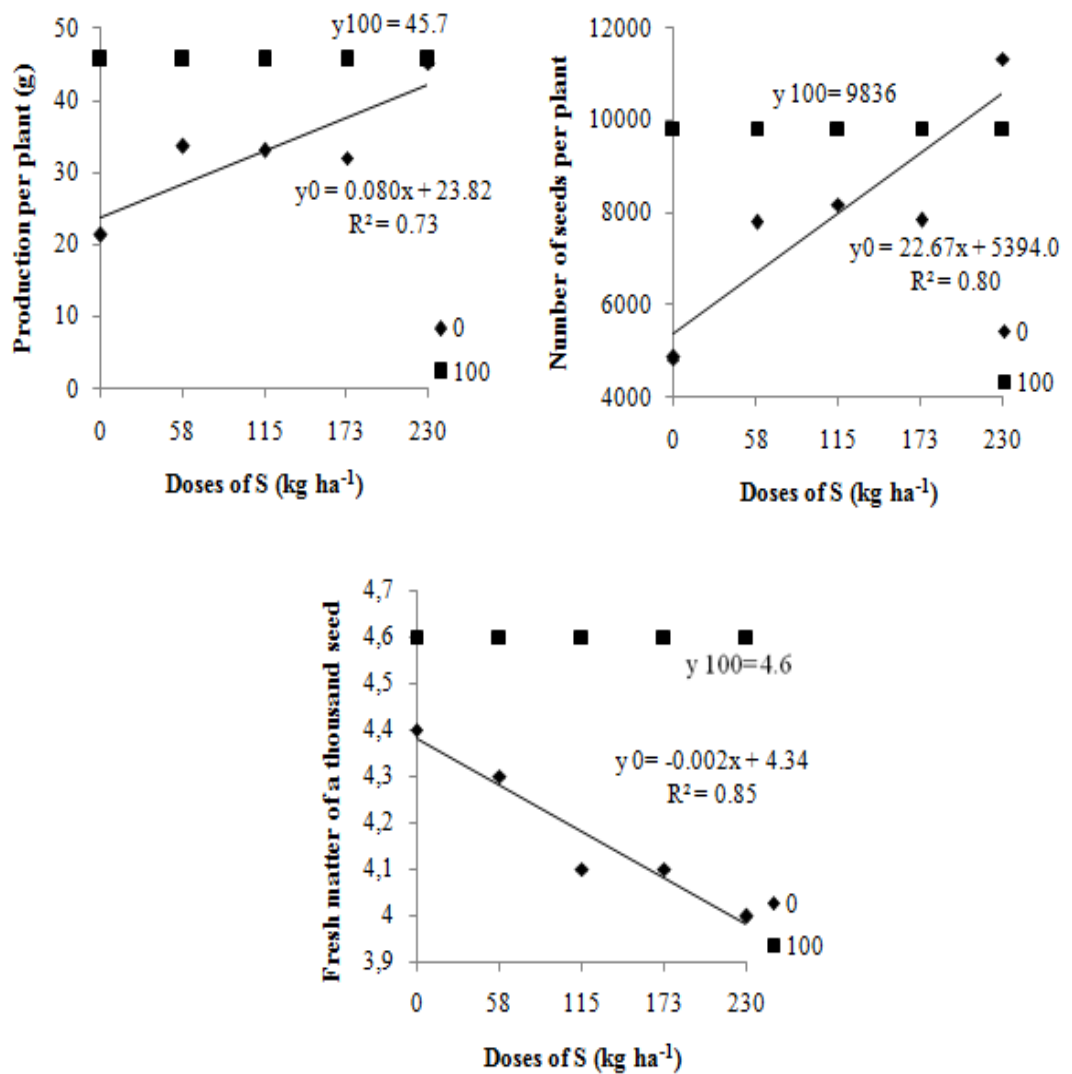

Fig 1. Production per plant, number of seeds per plant and mass of a thousand seeds by the doses of sulphur topdressing.FCA/UNESP, São Manuel. 2014.

Table 2. Extraction of nitrogen $(\mathrm{N})$, phosphorus $(\mathrm{P})$, potassium $(\mathrm{K})$, calcium $(\mathrm{Ca})$, magnesium $(\mathrm{Mg})$ and sulphur $(\mathrm{S})$ in broccoli seeds in the presence or absence of organic compost $\left(100 \mathrm{t} \mathrm{ha}^{-1}\right)$ before planting.FCA/UNESP,São Manuel, 2014.

\begin{tabular}{lcccccc}
\hline Compost $\left(\mathrm{t} \mathrm{ha}^{-1}\right)$ & $\mathrm{N}$ & $\mathrm{P}$ & $\begin{array}{c}\mathrm{K} \\
\left(\mathrm{mg} \mathrm{plant}^{-1}\right)\end{array}$ & $\mathrm{Ca}$ & $\mathrm{Mg}$ \\
\hline 0 & $1444.5 \mathrm{~b}$ & $195.4 \mathrm{~b}$ & $266.2 \mathrm{~b}$ & $199.6 \mathrm{~b}$ & $95.1 \mathrm{~b}$ & $313.1 \mathrm{~b}$ \\
100 & $2142.9 \mathrm{a}$ & $290.0 \mathrm{a}$ & $368.2 \mathrm{a}$ & $278.2 \mathrm{a}$ & $134.8 \mathrm{a}$ & $436.8 \mathrm{a}$ \\
\hline $\mathrm{CV}(\%)$ & 16.03 & 15.59 & 19.61 & 17.62 & 13.13 & 15.67 \\
\hline
\end{tabular}



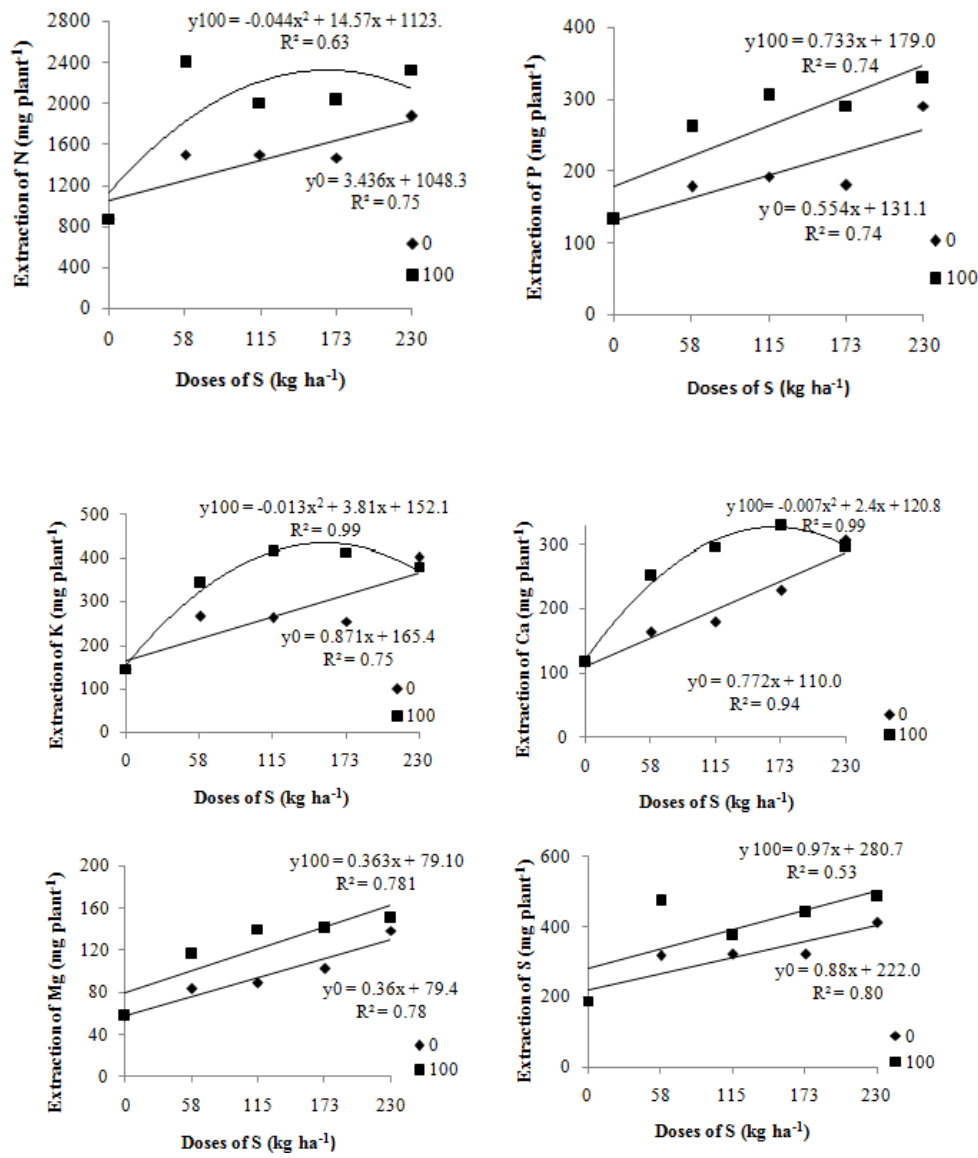

Fig 2. Extraction of nitrogen $(\mathrm{N})$, phosphorus $(\mathrm{P})$, potassium $(\mathrm{K})$, calcium $(\mathrm{Ca})$, magnesium $(\mathrm{Mg})$ and sulphur $(\mathrm{S})$ in broccoli seeds per plant by the doses of sulphur topdressing.FCA/UNESP, São Manuel.2014.

with organic compost. However, the other characteristics, such as total germination $(\mathrm{G})$, first count (FC), germination index rate (GIR), and seedling fresh mass (SFM) did not show any significant differences. The total germination and FC showed the same average, as it was only observed in new germinated seeds at the $5^{\text {th }}$ day, which was the date of the first count. Consequently, it is demonstrating a high physiological quality of the seeds.

It is noteworthy that prior to the evaluation, all irregular seeds and debris were eliminated through a seed density separator, i.e. in the same way as companies do before commercializing seeds. Therefore, most of the assessments did not show any differences for the quality of the seeds. When there was a difference, it was a small increase in vigour with organic compost, i.e. a higher SL (Table 1). By evaluating the doses of organic compost in the production of broccoli seeds, Magro et al. (2010) found no difference in germination and vigour of seeds evaluated shortly after harvesting and after 12 months of storage. However, a linear reduction was observed in germination and vigour (GIR and FGC) after 24 months, according to the lowest dose of organic compost applied before planting

The seeds produced under marginal fertility conditions are usually as viable and vigorous as those produced under more favourable conditions, according to Delouche (1980). In this case, the fertilization would basically influence the number of produced seeds, not affecting the quality. The typical response of plants to low fertility soil is the reduction in the amount of seeds produced, causing reduction in seed quality. The reducing of production without affecting the quality of seeds has been observed by many authors who also studied doses of organic and mineral fertilizers in the production of vegetable seeds (Kano et al., 2006; Magro et al., 2010; Quadros et al., 2012). In the current study, we observed effect on seed production, but there was no statistical significant difference for most quality traits. However, there was a little reduction in seed vigour in the absence of organic compost, which is contradictory to the hypothesis suggested by Delouche (1980), whose production was more affected than the quality itself.

Among all factors affecting seed quality, there are factors such as source of seeds, weather conditions at the stage of maturation and harvesting, drying, storage conditions, the sanity of the field production and fertilization. However, a few studies have been done to determine the relationship between the fertility of the soil, nutrients supply of plants and the quality of seeds; thus, further researches are needed.

\section{Accumulation of nutrients in seeds}

Regarding to the organic compost, a higher nutrient accumulation was obtained in the presence of organic 
compost $\left(100 \mathrm{t} \mathrm{ha}^{-1}\right)$ (Table 2). Also, a linear increase in seed mass per plant was observed by enhancing the doses of sulphur (Fig. 1), and a larger mass in the presence of organic compost (Table 1). These results were expected since nutrient accumulation depends to dry mass accumulation. Regarding to the doses of sulphur, a linear increase was observed to the equation for all macronutrients extracted in the absence of organic compost at planting time. However, in the presence of organic compost $\left(100 \mathrm{t} \mathrm{ha}^{-1}\right)$ at planting time, a linear adjustment was obtained for $\mathrm{P}, \mathrm{Mg}$ and $\mathrm{S}$. For the other macronutrients, a quadratic function occurred, being the average estimated in $2329.2,431.4$ and $326.5 \mathrm{mg} \mathrm{plant}^{-1}$ at the maximum doses estimated in 165.56, 146.50 and 171.42 for N, K and Ca, respectively (Fig. 2).

At the beginning of the reproductive stage, the nutrition requirements are more intense in most species. It is also critical at seeds formation, because a considerable amount of nutrients are transported to them (Carvalho and Nakagawa, 2012). Then, there will only be a higher seed production and an increase in nutrient accumulation whether nutrients are available to plants. Therefore, the greater the amount of fertilizer is, the larger the nutrients availability would be. Unless, there is some nutrient excess that may cause toxicity, salinity or nutritional imbalance, which is unlikely, as there is a linear increase in production (Fig. 1) and accumulation (Fig. 2).

The decreasing order of the macronutrients accumulated for the seeds was nitrogen>sulphur> potassium> phosphorus> calcium > magnesium. This order was similar to that observed by Magro et al. (2009), evaluating doses of organic compost in the production of broccoli seeds. These authors observed the following descending order of macronutrients accumulated in seeds: nitrogen $>$ sulphur $>$ phosphorus $>$ potassium $>$ calcium $>$ magnesium. Bearing in mind that sulphur is the second most nutrient accumulated in both studies.

In recent years, market has demanded productivity and reduction in production costs. Higher yields resulted on an increase in nutrients accumulation in plant seeds, seeds exportation, and higher amounts of fertilizers (inorganic and organic) to maintain the fertility of the soil.

It is important to know the content of plant, mainly after harvest, to evaluate and remove all nutrients from growing area; therefore, allowing to draw further recommendations about fertilization, i.e. necessary for a better fertilization management practice. On average, the plants have about 5\% of mineral nutrients in dry mass, but there are some differences between species, and the total quantity required for a crop depends on the productivity. On the other hand, nutrient uptake differs according to the stage of plant development, increasing with flowering, formation and growth of seeds and fruits (Carvalho and Nakagawa, 2012).

\section{Materials and Methods}

\section{Location and soil classification}

The experiment was conducted in the Sao Manuel Experimental Farm, Botucatu School of Agronomy, UNESP ( $22^{\circ} 46$ 'S, $48^{\circ} 34^{\prime} \mathrm{W} ; 740 \mathrm{~m} \mathrm{~m}$ altitude; climate type Cwa, according to Köppen's classification). The mean annual rainfall of São Manuel is $1377 \mathrm{~mm}$; and the mean annual temperature is $22^{\circ} \mathrm{C}$. The soil is classified as Dystrophic Red Latosol (Oxisoil).

Soil samples were collected at a depth of $0-20 \mathrm{~cm}$ to determine their chemical properties: $\mathrm{pH}$ in $\mathrm{CaCl}_{2}, 6.0$; M.O., $10 \mathrm{~g} \mathrm{dm}^{-3}$; Presin, $90 \mathrm{mg} \mathrm{dm}^{-3}$; $\mathrm{H}+\mathrm{Al}, 14 \mathrm{mmol}_{\mathrm{c}} \mathrm{dm}^{-3} ; \mathrm{K}, 3.2$ $\mathrm{mmol}_{\mathrm{c}} \mathrm{dm}^{-3}$; Ca, $24 \mathrm{mmol}_{\mathrm{c}} \mathrm{dm}^{-3} ; \mathrm{Mg}, 8 \mathrm{mmol}_{\mathrm{c}} \mathrm{dm}^{-3} ; \mathrm{SB}, 35$ mmol $_{\mathrm{c}} \mathrm{dm}^{-3}$; CTC, $49 \mathrm{mmolcdm}^{-3}$; V\%, 72; S, $4.0 \mathrm{mg} \mathrm{dm}^{-3}$

\section{Plant materials and experimental design}

The experimental design was a randomized complete block, with ten treatments $(5 \times 2$ factorial design $)$ and four repetitions. Treatments consisted of five doses of $\mathrm{S}$ topdressing $\left(0,58,115,173\right.$ and $\left.230 \mathrm{kgha}^{-1}\right)$ in the presence or absence of organic compost $\left(100 \mathrm{t} \mathrm{ha}^{-1}\right)$ at planting.

Prior to the treatments, the soil was prepared based on the recommendations by Raij et al (1997), in which we applied $60 \mathrm{~kg} \mathrm{~N} \mathrm{ha}^{-1}, 200 \mathrm{~kg} \mathrm{P}_{2} \mathrm{O}_{5} \mathrm{ha}^{-1}$, and $120 \mathrm{~kg} \mathrm{~K}_{2} \mathrm{O} \mathrm{ha}^{-1}$ into the whole site at planting time. Urea, triple superphosphate and potassium chloride were applied as sources of nitrogen, phosphorus and potassium, respectively. The organic compost was incorporated into the soil 15 days before transplanting of seedlings. The organic compost Provaso ${ }^{\circledR}$ was chosen and its chemical analysis showed values of $\mathrm{pH}$ 8.2, and M.O, 13.3, N, 0.43, $\mathrm{P}_{2} \mathrm{O}_{5}, 0.62, \mathrm{~K}_{2} \mathrm{O}, 0.48, \mathrm{Ca}, 1.61$, $\mathrm{Mg}, 0.17$, and $\mathrm{S}, 0.20$, all expressed in $\mathrm{g} \mathrm{kg}^{-1}$ of dry mass. The ratio of $\mathrm{C} / \mathrm{N}$ was $19 / 1$ and the moisture content of the compost was $38 \%$.

The topdressing fertilization consisted of nitrogen $(200 \mathrm{~kg}$ $\mathrm{N} \mathrm{ha}{ }^{-1}$ ) and potassium $\left(120 \mathrm{~kg} \mathrm{~K}_{2} \mathrm{O} \mathrm{ha}^{-1}\right)$, in accordance within the maximum doses recommended by Raij et al. (1997) for the commercial production of broccoli. The higher doses can be explained by the fact that when seeds are produced, increases the crop cycle, probably, the need for higher doses to meet the crop's demand. Doses of sulphur were calculated considering the use of ammonium sulphate (as a source of nitrogen). Considering $100 \%$ of $\mathrm{N}$, as ammonium sulphate $(20 \% \mathrm{~N}, 23 \% \mathrm{~S})$, we reached to the maximum dose of $\mathrm{S}\left(230 \mathrm{~kg} \mathrm{ha}^{-1}\right)$. The other doses accounted for 75,50 and $25 \%$ of this maximum dose. In addition to the dose of N, urea was used $(45 \% \mathrm{~N})$. For source of potassium, potassium chloride $\left(60 \% \quad \mathrm{~K}_{2} \mathrm{O}\right)$ was used. The cultivar Santana was chosen as plant material. On March 06, 2014, sowing was performed in polypropylene trays of 200 cells, containing coconut fibre substrate. On March 26, 2014, seedlings were transplanted at a spacing of $0.8 \times 0.6 \mathrm{~m}$, whereas three lines with 5 plants in each plot, totalling 15 plants per plot, but only evaluating the middle 3. Sprinkler irrigation and weed control were used. In the $\mathrm{S}$ topdressing fertilization, sulphur was applied three times, every 15 days after transplanting. According to the methodology described by Raij et al. (1997), $\mathrm{N}\left(108 \mathrm{kgha}^{-1}\right)$ and $\mathrm{K}_{2} \mathrm{O}\left(90 \mathrm{~kg} \mathrm{ha}^{-1}\right)$ it were applied, $1 / 3$ of the respective dose in the same dates of the topdressing. The source of $\mathrm{N}$ and $\mathrm{S}$ was ammonium sulphate $(23 \% \mathrm{~S}$ and $20 \% \mathrm{~N})$. Additionally, source of $\mathrm{N}$ was completed with urea $(45 \% \mathrm{~N})$ and source of $\mathrm{K}$ was accomplished with potassium chloride $\left(60 \% \mathrm{~K}_{2} \mathrm{O}\right)$. The harvest was performed in a single day, i.e. 154 days after sowing. Once harvested, the seeds and the rest of the plant were taken into the dry chamber at $40 \%$ relative humidity and $20^{\circ} \mathrm{C}$ for better conservation. After threshing, the seeds were cleaned to remove any debris or low quality seeds in a seed density separator ('De Leo Type 1'model,calibrated at opening about $15 \%$ of the air flow area), sorting the seeds according to Magro et al. (2009). Then, the production was evaluated for seeds fresh mass, number of seeds per plant, mass of a thousand seeds (i.e. each block of 1000 seeds were counted and carried out to weigh in analytical balance with a precision of $0.001 \mathrm{~g}$ ), and physiological quality, germination and vigour (first count; germination index rate-GIR, seedling fresh mass and seedling length). The germination test was performed by using gerboxes in germinator at $20^{\circ} \mathrm{C}$ to analyze 100 seeds per block. The first count of normal 
seedlings was performed five days and the second on the tenth day (Brasil, 2009). Seedlings were considered germinated when it was noticed the appearance of the cotyledon leaves. The first count was considered as the vigour test. During the germination test, the GIR was obtained according to Maguire (1962) and the evaluations were performed daily, always at the same time until the tenth day after sowing. To obtain the seedlings fresh mass, all regular seedlings were weighed on the 10th day in analytical balance (with a precision of 0.0001) then the length of each seedling was determined. To determine the accumulation of nutrients, samples with $50 \mathrm{~g}$ of seeds per plot were dried in a forced-air-circulation oven at $65^{\circ} \mathrm{C}$ until constant mass. After that, the samples were brought into the Plants Chemical Analysis Laboratory to obtain the macronutrient content in the seeds (i.e. N, P, K, Ca, Mg and S). Each sample was ground through a Wiley mill. The sulphuric digestion was used to determine $\mathrm{N}$ and the nitric-perchloric acid digestion was used to determine the other nutrients $(\mathrm{P}, \mathrm{K}, \mathrm{Ca}, \mathrm{Mg}$ and S), as described by Malavolta et al. (1997).

From the chemical analyzes, the contents of N, P, K, Ca, $\mathrm{Mg}$ and $\mathrm{S}$ in $\mathrm{g} \mathrm{kg}^{-1}$. The amount of nutrients accumulated in the seeds was obtained by the ratio of the content of each nutrient and the seeds dry mass produced per plant in each plot.

Data were subjected to analysis of variance and regression for doses of S. In the presence or absence of organic compost, means were compared by Tukey test $(\mathrm{p}<0.05)$.

\section{Conclusion}

The production of broccoli seeds had a linear increase by enhancing the doses of sulphur and a higher production was observed in the presence of organic compost. However, the characteristics of seeds quality's, such as total germination $(G)$, first count (FC), germination index rate (GIR), and seedling fresh mass (SFM) did not affected by the doses of sulphur, even in the absence of organic compost. The decreasing order of the macronutrients accumulated for the seeds with and without organic compost was: nitrogen> sulphur $>$ potassium $>$ phosphorus $>$ calcium $>$ magnesium. Thus, the most nutrient accumulated in seeds were the $\mathrm{N}$ with and without organic compost. This $\mathrm{N}$ is due to the uptake of fertilizer base and topdressing, by which application of organic compost duplicated the accumulation of $\mathrm{N}$.

\section{Acknowledgments}

The authors would thank to the Coordination for the Improvement of Higher Education Personnel (CAPES) and National Council for Scientific and Technological Development (CNPq) and grant \#2016/13915-5, São Paulo Research Foundation (FAPESP) to scholarship granted for the studies.

\section{References}

Abd El-Hamed KE, Elwan MWM (2010) Genotype by environment interactionand phenotypic stability of yield and quality in broccoli (Barassica oleracea var. italica). J Agric Sci. 1(6): 819-835.

Abbey L, Jouce DC, Aked J, Smith B (2002) Genotype, sulfur nutrition and soiltype effects on growth and dry matter production of spring onion. J Hortic Sci Biotech. 77(3): 340-345.

Berry PM, Spink J, Foulkes MJ, White PJ (2010). The physiological basis ofgenotypic differences in nitrogen use efficiency in oilseed rape (Brassica napus L). Field Crops Res. 119:365-373.

Biswas BC, Tewatia RK (1991) Role of sulfur in balanced plant nutrition Indian experience. Paper presented at the Proceedings of the International Symposium on the Role of Sulfur, Magnesium and Micronutrients in Balanced Plant Nutrition, The Potash and Phosphate Institute of Canada, 98-106 1991.

Brasil - Ministério da Agricultura, Pecuária e Abastecimento (2009) Regras para análise de sementes. Brasília, Mapa/ACS.

Buchanan BB, Gruissem W, Jones RL (2015) Biochemistry \& Molecular biology of plants. American Society of plant Biologists. Second edition. USA, Oxford, 1283p.

Carfagna S, Vona V, Di Martino V, Esposito S, Rigano C (2011) Nitrogen assimilation and cysteine biosynthesis in barley: evidence for root sulphur assimilation upon recovery from $\mathrm{N}$ deprivation. Environ Exp Bot. 71(1): 18-24.

Carvalho NM, Nakagawa J (2012) Sementes: ciência, tecnologia e produção. 5. ed. Jaboticabal, FUNEP.

Corrêa CV, Cardoso AII, Cláudio MTR (2013) Produção de repolho em função de doses e fontes de potássio em cobertura. SeminCienc Agrar. 34 (5): 2129-2138.

Corrêa CV, Gouveia AMS, Martins, BNM, Tavares, AEB, Lanna NBL, Cardoso AII, Evangelista, RM (2016) Response of broccoli to sulphur application at topdressing in the presence or absence of organic compost at planting. Afr J of Agric Res. 11(35): 3287 3292.

Delouche JC (1980) Environmental effects on seed developtment and seed quality. HortiScience.15 (6): 775-780.

Dinkova-Kostova AT, Kostov RV (2012) Glucosinolates and isothiocyanates in health and disease. Trends Mol Med. 18(6): 337-347.

Eriksen J, Thorup-Kristensen K, Askegard M (2004) Plant availability of catch crop sulfur following spring incorporation. J Plant Nutr Soil Sci. 167(5): 609-615.

George RAT (2009) Vegetable seed production. 3. eds. Walligford, UK, CABI.

Kano C, Cardoso AII, Higuti ARO, Villas Bôas RL (2006) Doses de potássio na produção e qualidade de sementes de alface. Hortic Bras. 24 (3):356-359.

Konstantopoulou E, Kapotis G, Salachas G, Petropoulos SA, Karapanos IC, Passam HC (2010) Nutritional quality of greenhouse lettuce at harvest and after storage in relation to $\mathrm{N}$ application and cultivation season. Sci Hortic-Amsterdam. 125(2): 93-95.

Latté KP, Appel KE, Lampen A (2011) Health benefits and possible risks of broccoli - an overview. Food Chem Toxicol. 49(12): 3287 . 3309.

Magro FO, Cardoso AII, Fernandes DM (2009) Acúmulo de nutrientes em sementes de brócolis em função de doses de composto orgânico. Cultivando o Saber. 2: 49-57.

Magro FO, Arruda N, Casa J, Salata AC,Cardoso AII,Fernandes DM ( 2010) Composto orgânico na produção e qualidade de sementes de brócolis. Cienc Agrotec. 34 (3): 596-602.

Maguire JD (1962) Speeds of germination-aid selection and evaluation for seddling emergence and vigor.Crop Sci. 2: 176-177.

Malavolta EA, Vitti GC, Oliveira AS (1997) Avaliação do estado nutricional das plantas: princípios e aplicações. 2 ed. Piracicaba: Potafós. 201p.

Quadros BR, Corrêa CV, Cardoso AII (2012) Influência de composto orgânico e fósforo sobre sementes de alface. Semin- Cienc Agrar. 33 (1): 2511-2518

Raij BV, Cantarella H, Quaggio JA, Furlani AMC (1997) Recomendações de adubação e calagem para o Estado de São Paulo. 2. ed. Campinas, IAC.

Rathke GW, Behrens T, Diepenbrock W (2006) Integrated nitrogen management strategies to improve seed yield, oil content and nitrogen efficiency of winter oilseed rape (Brassica napus L.): A review. Agric. Ecosyst. Environ. (117):80-108

Salvagiotti F, Miralles DJ (2008) Radiation interception, biomass production and grain yield as affected by the interaction of nitrogen and sulfur fertilization in wheat. Eur J Agron. 28(3): 282290.

Schonhof I, Blankenburg D, Mueller S, Krumbein A (2007) Sulfur and nitrogensupply influence growth, product appearance, and glucosinolate concentration of broccoli. J Plant Nutr Soil Sci. 170: $1-8$.

Traka M, Mithen R (2009) Glucosinolates, isothiocyanates and human health. Phytochem Rev. 8: 269-282.

Veeranki OL, Bhattacharya A, Marshall JR, Zhang Y (2013) Organspecific exposure and response to sulfora phane, a key chemo preventive ingredient in broccoli: implications for cancer prevention. Br J Nutr. 109(1): 25-32. 